U.S. DEPARTMENT.OF THE INTERIOR

U.S. GEOLOGICAL SURVEY

\title{
MAP SHOWING THE DISTRIBUTION OF ANOMALOUS CONCENTRATIONS OF MERCURY, ANTIMONY, AND ARSENIC IN STREAM SEDIMENT, HEAVY-MINERAL CONCENTRATE, AND AQUATIC MOSS IN THE IDITAROD QUADRANGLE, ALASKA
}

By John E. Gray, Peter F. Folger, and Philip L. Hageman

\section{ॠUSGS \\ science for a changing world}

MISCELLANEOUS FIELD STUDIES MAP

Published by the U.S. Geological Survey, 1997

ISBN $060788365-0$

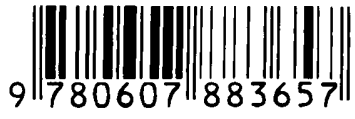




\section{INSERT FOR MF-2219-C}

Corrections and additions for: U.S. Geological Survey Miscellaneous Field Studies Map MF-2219-C, Map showing the distribution of anomalous concentrations of mercury, antimony, and arsenic in samples of stream sediment, heavymineral concentrate, and aquatic moss in the Iditarod quadrangle, Alaska

In the References section, the title of Miller and Bundtzen (1994) is incorrect and the correct reference is:

Miller, M.L., and Bundtzen, T.K., 1994, Generalized geologic map of the Iditarod quadrangle, Alaska, showing potassium-argon, major-oxide, trace-element, fossil, paleocurrent, and archaeological sample localities: U.S. Geological Survey Miscellaneous Field Studies Map MF-2219-A, 1 plate, scale 1:250,000, 48 p.

The geologic base for the map and the geologic descriptions in the Description of Map Units section are from Miller and Bundtzen (1994). 